\title{
Charismatic violence and the sanctification of the super-rich
}

\author{
Linsey McGoey and Darren Thiel
}

\begin{abstract}
Drawing historical comparisons between the $19^{\text {th }}$ century and the present, this paper describes and analyses how an elite section of the global rich, through mega-giving and a re-emerging notion of 'noblesse oblige' that is enshrined in the philanthrocapitalism movement, have fostered a sacred rationale for their extreme wealth. Not only do the new nobles hold the power of wealth but, through mega-giving, they generate a moral imagery akin to religious figures who ostensibly self-sacrifice for the good of everyone else. This generates a form of charismatic authority that affords the super-rich an influential space from which to spread a 'theodicy of privilege' - legitimating their elevated economic position, shielding growing wealth concentration from criticism, and sanctifying the claim that individual mega-wealth is collectively beneficial. Through its contribution to and facilitation of the inegalitarian status quo, this theodicy engenders various forms of structural violence. Here we explore the mechanisms that enable wealthy donors to position themselves as apparent benefactors of humanity, including a reliance on metrics that appear to justify the claim that targeted philanthropic expenditures can and are reducing global wealth and health inequalities, but which raise unanswered questions surrounding the actual effects of the outcomes claimed.
\end{abstract}

Keywords: inequality; philanthrocapitalism; theodicy; gifts; charisma; violence.

Linsey McGoey, Department of Sociology, University of Essex, Wivenhoe Park, Colchester, CO4 3SQ, United Kingdom. Email: Imcgoey@essex.ac.uk

Darren Thiel, Department of Sociology, University of Essex, Wivenhoe Park, Colchester, CO4 3SQ, United Kingdom. Email: djthiel@essex.ac.uk 


\section{Introduction}

In a short and neglected chapter of Democracy in America, Alexis de Tocqueville raises longoverlooked questions that are useful for understanding today's wealth elites, their philanthropy, and their influence over human welfare.

Entitled 'How an aristocracy may be created by industry,' Tocqueville opens the chapter with an observation that reiterates Adam Smith's earlier concerns about the corroding influence of an increased division of labour on the mental faculties of workers. Writing in the 1830s and pre-empting the work of Marx and later authors such as Braverman (1974), Tocqueville suggested that as work tasks became more minute, intricate and specialized: 'the workman becomes weaker, more limited, and more dependent. The craft improves, the craftsman slips back... At the same time that industrial science constantly lowers the standing of the working class, it raises that of the masters' (1966: 556).

Tocqueville argues that, because of this process, a new and unprecedented class of nobles was emerging - something he termed a 'business aristocracy'. Here, industrial science and organisation had elevated industrial leaders to a position of superiority over labourers whereby 'One is in a state of constant, narrow and necessary dependence on the other and seems to have been born to obey, as the other was to command. What is this, if not an aristocracy?'(1966: 557).

Even within a society that is democratic, or, as Tocqueville identified, particularly within a society that is democratic and where citizens have formal equality of opportunity before the law, he sensed that the rapid rise of industrialization had already generated an unprecedented type of social hierarchy. Tocqueville labelled this form of domination a 'monstrosity' because the industrial overlords were indifferent to their direct role in immiserating their workers: 
The territorial aristocracy of past ages was obliged by law, or thought itself obliged by custom, to come to the help of its servants and relieve their distress. But the industrial aristocracy of our day, when it has impoverished and brutalized the men it uses, abandons them in time of crisis to public charity to feed them (558).

Tocqueville urged the new industrial aristocrats emerging in the United States, England and France to reinvent and re-apply feudal notions of duty towards the less advantaged, and, today, his call for an enhanced sense of personal obligation among the new rich is being revived. Hailed across the left and the right as a way to channel the exceptional resources of the super-rich in order to 'solve' the world's most pressing problems, philanthrocapitalism has come to ostensibly fulfil this obligation and also take on an almost sacred position in contemporary sermons on human progress.

This paper explores the rhetoric and growing political influence of contemporary exponents of Tocqueville's vision of a duty-bound elite class - the new philanthrocapitalists whose enormous personal fortunes have become legitimated partly by giving some of those fortunes away. We suggest that the new philanthropists both resemble and differ from Tocqueville's $19^{\text {th }}$ century vision of wealthy donors in important and unacknowledged ways, particularly when it comes to their different positions on the compensatory rationale for philanthropic giving.

We have four aims. First, we consider the notion 'noblesse oblige', situating its history in a discussion of what is and is not distinctive about today's philanthrocapitalism movement. Second, we compare Tocqueville's writing on charity to what Max Weber and Pierre Bourdieu called 'theodicies of the privileged' - self-legitimating narratives that individuals in different social positions are compelled to use to explain and justify their relative status. Third, we develop the concept 'charismatic violence' in order to conceptualise 
various forms of epistemic and actual injury that are connected to the super-rich and their mega-giving. Lastly, we use the examples of a number of philanthrocapitalist foundations and the growing 'effective altruism' movement to explore how charismatic violence functions in practice. Our argument is that the growing salience of new and purportedly more efficient forms of private philanthropic giving obscures key mechanisms through which the power of wealth elites - and their accompanying legitimation - has increased and consolidated inequality.

\section{Tocqueville on the industrial aristocrats: elite duty in historical context}

Tocqueville is occasionally seen as a critic of democracy, as someone who feared and resented the growing power of an ill-informed public. The reality is more nuanced. He was strongly in favour of democratic rule and the decline of inherited privilege. But he was also wary of new sources of tyranny that were, as he put it, 'immaterial' in nature - that could not necessarily be directly traced to physical forms of restraint or prohibition but which nonetheless hindered the scope for freedom of thought among individuals in democratic nations.

One of these potential sources of tyranny was the rise of industrial 'masters' who felt no responsibility for the brutal working conditions and injurious livelihoods of their own workers. Business elites were free to cultivate their intellect and compound their own personal fortunes, while the typical labourer was 'assigned a certain position in society which he cannot quit. In the midst of universal movement, he is stuck immobile' (1966[1835]: 556).

Tocqueville had two main concerns about the growing inequality between manufacturers and workers. Firstly, the new rich themselves, despite becoming ever more powerful, had no common link among themselves - in Tocqueville's words, 'there [is] no 
solidarity among the rich' (1966[1835]: 557). Secondly, he suggested that there was no longer a sense of the mutual interdependency between the poor and the rich, leading him to state that the 'manufacturing aristocracy which we see rising before our eyes is one of the hardest that have appeared on earth' (1966[1835]: 557). Although he doesn't expand on what he means by 'hardest', the context suggests he means 'hard' in the sense of being particularly indifferent or uncaring towards the plight of the poor. He then quickly adds a caveat. In the same paragraph he states that the new manufacturing aristocracy is also 'one of the most restrained and least dangerous' (1966[1835]: 557).

How can the new, burgeoning aristocracy that Tocqueville identifies among nineteenth-century US manufacturers be the 'hardest' and yet the least dangerous? His reasoning is both complex and instructive. On the one hand, he was glad that class solidarity among the rich was waning: "what is most important for democracy is not that great fortunes should not exist, but that great fortune should not remain in the same hands. In that way there are rich men, but they do not form a class' (Tocqueville, quoted in Himmelfarb 1997: 11; see also Storey 2013).

Tocqueville was hopeful that their lack of class solidarity prevented industrial elites from becoming an irremovable set of unelected industrial masters. Yet he also saw a social cost to their lack of organization: he was worried that the new rich would underestimate their own direct role in creating and compounding their workers' suffering, hence why he appeals time and again to the new rich to honour their obligations to the poor.

At first glance, it seems as if Tocqueville's appeal to the rich has been realized today, at a time when many philanthropists are adamant that the wealthy have some form of duty to share at least some of their fortunes. However, in many ways, this is a sense of duty divorced from a sense of liability or obligation - and more about the personal choice of the 'good' super-rich. By contrast, in feudal times, the injustices of birth position - the perception that 
an elite few were born to lead while others were born to serve - fostered a philanthropy of recompense. This earlier, feudal ethos is captured by the phrase 'noblesse oblige', conveying the belief that those who have been bestowed honours or wealth through hereditary privilege owe a debt to those on which their advantage relied upon.

The term 'noblesse oblige' is believed to have been coined by the novelist Honoré de Balzac in 1835 - the same year that Tocqueville published his first Democracy volume. Balzac introduces the phrase in a novel, The Lily of the Valley, where he calls it 'an old idea'. The phrase is written in a letter to a young aristocratic man who is imparted 'two oldfashioned words, "Noblesse oblige" - and the young man is told that with noble privileges comes the obligation of service to others. Balzac was an explicit monarchist and defender of the French nobility; his coinage of the term 'noblesse oblige' suggests that notions of elite obligation remained entrenched in early $19^{\text {th }}$-century aristocratic circles even despite or, because of, the ebbing of feudal privileges following the French revolution. ${ }^{1}$

The notion of noblesse oblige was clearly influential on Tocqueville's thought and, in a different form, it is resurgent today in the philanthrocapitalism movement. Writing at the turn of the $20^{\text {th }}$ century, Andrew Carnegie was one of the earliest modern philanthropists to popularize a neo-feudal notion of noblesse oblige, insisting in essays such as 'The Gospel of Wealth' that the rich have a duty to gift their wealth to others. In Carnegie's oft-cited words, 'the man who dies rich dies thus disgraced' (Carnegie 1996: 12). However, today, Carnegie's call of duty has become spectacularly enshrined in initiatives such as the 'Giving Pledge', a movement established by the philanthrocapitalist nobles, Bill Gates and Warren Buffett, which by 2016 had attracted over 200 billionaires to commit to giving away large proportions of their wealth in their lives. ${ }^{2}$

Despite its importance, the concept of noblesse oblige does not figure prominently in contemporary analyses of the increasing centrality of philanthropy in debates about human 
suffering and disadvantage. ${ }^{3}$ Yet we see it as essential for understanding the increasingly powerful discourse on private giving as a solution to suffering and inequality in contemporary societies that, at face value, seem to have dispensed with aristocratic privilege - but which is re-emerging in a different form under the canopy of the 'new' philanthrocapitalism. To understand what's unique about the new noblesse oblige, it is first useful to see what's unique about the 'new' philanthrocapitalism.

\section{Philanthrocapitalism and the legitimation of rich-to-rich giving}

Philanthrocapitalism is defined in two key ways. First, it's upheld as 'a new way of doing philanthropy, which mirrors the way that business is done in the for-profit capitalist world.' Secondly, the notion is seen as encapsulating the belief that 'capitalism itself can be philanthropic, working for the good of mankind' (Bishop and Green 2008). ${ }^{4}$

Now over ten years old, the term has attracted growing scholarly attention (see Birn 2014; Eikenberry and Mirabella 2017; Fridell and Konings 2013; Harman 2016; Kish and Justin 2015; Kohl-Arenas 2015; Kuldova 2017; Rogers 2011; Thorup 2013), but only a handful of observers have emphasized a notable point about this supposedly 'new' concept that it is not actually new. As Edwards (2011) and McGoey (2012; 2015) have pointed out, the ideas underpinning philanthrocapitalism echo a core tenet of $18^{\text {th }}$-century political economy: the debatable and much-contested idea that 'enlightened' self-interest helps to fuel an economic dynamism that inevitably improves collective living standards.

Although the ideas behind the term have a long history, what's notable today is that philanthrocapitalist enthusiasts have managed to successfully rebrand an $18^{\text {th }}$-century notion as a radically new idea. By positing the concept as ground-breaking, the new philanthrocapitalists have attracted considerable media attention as well as enrolled 
influential adherents as 'believers', including eBay founder Pierre Omidyar and Facebook chief Mark Zuckerberg, who, like those other billionaires that signed up to the Giving Pledge, have embraced the idea that large-scale private wealth-creation is inevitably beneficial for humankind. These believers have, in turn, spearheaded a number of influential policy and legislative changes that are indeed different from the past (see Dowling 2016; Rogers 2011), and which have yielded significant power and influence to the new super-rich as a result. ${ }^{5}$

The assumption that extreme private wealth is, in itself, a public good was widely derided in Carnegie and Rockefeller's time. Yet, this is no longer the case today, and comprehending this change is key to understanding what's new about contemporary philanthocapitalism. Indeed, today, philanthropy is increasingly hailed as 'the new risk capital' for private companies, with growing calls to direct grants to the 'companies that need it the most' (Braemer 2015; see Aschoff 2015 and Jenkins 2011 for criticisms of this trend).

In other words, while the notion of philanthrocapitalism is old, claims of its novelty have generated real effects, leading to institutional changes within the non-profit sector that are entirely without precedent. These include both Omidyar and Zuckerberg each establishing for-profit limited liability companies (LLCs) to purportedly 'gift' their wealth - a move that enables them to sidestep government laws regulating more traditional private philanthropic trusts (Singer and Isaac 2015). While other donors such as Gates and Buffett have not formed LLCs to disburse their fortunes, they are engaging in other forms of 'rich-to-rich giving' whereby large sums of money are donated directly to some of the world's largest credit companies and for-profit education publishers, including Mastercard and Scholastic - a practice that interprets current US charity regulations in very creative and possibly illegal ways (McGoey 2015).

US legal duties incumbent on traditional philanthropic trusts are rooted in two longstanding legal principles. The first is that organizations that receive tax exemptions must 
ensure their giving contributes to general and not private welfare, hence limits on what is known as 'self-dealing' - any conduct that enables a trustee or a founder of a philanthropic entity to exploit his or her position for private gain. The second is underpinned by the idea that private fortunes should not be used to subvert government policies enacted by public officials who have a democratic mandate to act on behalf of a general public; hence restrictions on partisan lobbying. Both principles are premised on the belief - that is deeply rooted in western notions of good governance - that public welfare and the private interests of different stakeholders do not inevitably or naturally align (Barman 2017; Cullman and Madoff 2016; Parmar 2012; Reich et al 2016; Vogel 2006; Zunz 2011).

Today, while regulatory restrictions against 'self-dealing' are still formally in place, some influential philanthropic donors are creatively skirting them. For example, by establishing an LLC, Zuckerberg legally avoids the need to publicly disclose the names of the recipients of his philanthropic investments, a requirement that more traditional trusts such as the Gates Foundation must comply with. It also means he can give all his 'philanthropic' grants to for-profit companies or other private individuals, including to himself. Yet, in establishing a for-profit company rather than a traditional foundation, Zuckerberg elicited global praise while simultaneously avoiding US laws aimed at deterring the very thing that he is now able to do with legal impunity: to profit financially from philanthropic giving (Eisinger 2015).

This marks a significant change from the past. Until very recently, scholars of philanthropy tended to presume that a gift's self-serving objectives must be strategically veiled in order to be achieved (Schrift 1997). This perception is visible for instance in studies exploring the role of $20^{\text {th }}$ century US philanthropic foundations in furthering US foreign policy and commercial objectives abroad (see Fisher 1983; Parmar 2012). Here philanthropy 
is seen as deriving its cultural salience through its ability to obscure the capacity for private gain, and which must conceal the potential for gain in order to be seen as legitimate.

The need for veiling national and personal interest has however shifted in the early years of the $21^{\text {st }}$ century, a period when the capacity to merge financial gain with charitable ventures is explicitly hailed as the superior, distinguishing characteristic of the 'new' philanthropy. Today's philanthrocapitalists defend private wealth augmentation as 'naturally' beneficent in manner than dispenses with even the need for obfuscation. Indeed, many of today's influential mega-donors denigrate philanthropic gifts that don't generate for-profit returns as inefficient and therefore wasteful; hence the growing calls to offer more 'charity' directly to private companies - both explicitly and implicitly devaluing the worth of individuals who are unable to position themselves as 'deserving' recipients of either private or governmental financial aid (Boland and Giffin 2016; Thiel et al 2015; Allen et al 2015).

The advent of philanthrocapitalism has thus signalled a new entrenchment of what Barnett (2000) calls 'corporate populism' whereby the equivalence of corporate interests with public welfare is upheld as obvious and unchallengeable, as natural to the new philanthrocapitalists as a religious theodicy - and increasingly adhered to by less-affluent constituents who receive few obvious benefits from subscribing to the orthodoxy. Below, building on Weber and Bourdieu, we explore the 'theodicy of privilege' that has been augmented by and encapsulated in the philanthrocapitalist turn.

\section{Theorizing theodicy and the sanctification of the super-rich}

The term theodicy was first coined by Leibniz in the $17^{\text {th }}$ century, who braced the prefix of 'theos', or 'god', against 'dikē' to coin a word for a longstanding social practice: the effort to explain and justify why God permits human suffering to endure. Defined crudely, theodicies 
are belief systems that seek to understand God's willingness to tolerate pain and worldly suffering.

Building on Weber's analysis of religion, theodicy and social stratification, Bourdieu (1971), extended Leibniz's idea, adding the insight that the problem of theodicy remains acute even in secular times - indeed, if anything, it becomes even more acute when theological explanations for the persistence of suffering wane. Moreover, Bourdieu (1971; 1990; 2011) insists that theodicies are, above all 'sociodicies', in that they offer adherents a way to make one's relational position in a social hierarchy not simply palatable, but exceptional - and therefore worthy of self-respect. He argues:

If there are social functions of religion and, consequently, if religion is amenable to sociological analysis, it is because laypeople do not - or not only - expect from it justifications for existence capable of freeing them from the existential anguish of contingency... but also and above all justifications for existing in a determinate social position and existing as they exist (1991:16).

It is hardly an unfamiliar point to sociologists that theodicies-cum-sociodicies furnish a justification for determinate social positions 'existing as they exist', but it is a notion that affords a more radical interpretation of social hierarchy than has been acknowledged. Bourdieu hints at but, doesn't fully reach, the logical extreme of his argument: the way in which a theodicy's power rests in the ability to offer the solace of personal transformation and with it the hopefulness of collective transformation - to those whose actual social position need not change in order to experience that transformation.

At the same time, when it comes to dominant groups, Bourdieu sees that theodicies also function to legitimate their privilege - though providing culturally acceptable justifications for the dominant's elevated status. Explicitly rejecting a narrow reading of 'class interest' for understanding this form of social control, Bourdieu suggests instead that a 
'demand for compensation' among groups with 'negative privilege' imbues certain specialized figureheads with the authority to dispense religious 'goods' - and this authority tends to accord with and entrench existent social hierarchies. He argues that social stratification is often perpetuated by individuals who don't necessarily have a conscious aim to subjugate others or to accept subjugation but who nonetheless entrench existent inequalities through collective misperception of the ways that certain practices conform to and replicate an existent order.

One of Bourdieu's better-known examples is his suggestion that the current educational system helps 'to provide the dominant class with a "theodicy of its own privilege"” (Bourdieu 1990: 133). ${ }^{6}$ The ostensible inclusiveness of western education systems fuels 'misrecognition' of less tangible forms of capital that can hinder access to formal educational credentials, thus granting the privileged classes their self-belief that their own status is hard-earned, rather than reflecting inherited advantages.

In a related but somewhat less widely known argument, Bourdieu (1990) also points out that meritocratic systems in general tend to rely on charisma-based explanations emanating from their specialised figureheads in order to justify the fact that nominally 'inclusive' realms such as public education and commerce are often markedly exclusive in practice. He even uses he words 'meritocratic' and 'charismatic' interchangeably so as to underscore his view that, by necessity, meritocratic societies tend to sanctify the illusion of personal 'gifts' in order to rationalize gross differentials in social and economic outcomes:

This is true, for example, of the charismatic (or meritocratic) ideology, a particular form of the giving of 'gifts', which explains differential access to qualifications by reference to the inequality of innate 'gifts', thereby reinforcing the effect of mechanisms that mask the relationship between qualifications obtained and inherited cultural capital (1990: 133). 
Bourdieu's insights into charisma have been considered extensively in the sociology of religion (see Joosse 2014; Turner 2013; and Stolz et al 2008), but there is less literature exploring the relationship between charisma and contemporary philanthropy, a sector where the charismatic exceptionality of a new generation of mega-donors is helping to entrench a debatable assumption: the belief that extreme wealth inevitably signifies personal 'giftedness' and therefore an acumen for 'solving' global problems, rather than reflecting structural advantages afforded by family connections, cultural and symbolic capital, and extensive government welfare in support of corporations and 'high-worth' individuals.

This tendency is particularly acute in the United States, where, as Tocqueville suggested, there is a long-standing cultural tendency to see wealth as a sign of distinction and where therefore it's not surprising that individuals who made their fortunes in entrepreneurial industries are particularly hailed for their problem-solving talents. Perhaps more so than in Europe, great wealth in the US is seen as evidence of an individual's 'natural' exceptionality, signifying the polar contrast to inborn privilege (Fourcade 2011).

While belief in the divine right of kings and their aristocracy has slowly eroded over the past millennium, the notion of personal giftedness - a notion embedded in religious symbolism whereby it is God who disburses worldly gifts (see Weber 1993; 2001) continues to furnish the dominant with a justification for their own elevated status and good fortune. Combined with the notion of noblesse oblige, it also becomes a mechanism that makes the superior status of the rich palatable to the excluded - bolstered massively by the 'gifted' sharing some of their 'gifts' with the less fortunate.

What is remarkable today is that even when so-called 'gifts' are not necessarily shared with the less fortunate - such as when the Gates Foundation gifts its money to Mastercard executives and shareholders at a time of dramatically rising U.S. poverty levels; or when Zuckerberg structures his giving so that he alone can legally profit unrestrictedly 
from his 'gifts' - the semblance of personal self-sacrifice still fosters public regard and even reverence for their actions. This reverence signals an acceptance among the 'laity' of the righteousness of the new super-rich's 'theodicy of privilege'. Thus today, the idea that the pursuit of private financial gain is 'naturally' synonymous with the collective betterment of humanity, is largely uncontested - even as poverty levels rise dramatically in nations like the United States and the standard of living for most people living in other highly neo-liberal nations like the United Kingdom continues to decline. ${ }^{7}$

The re-emergence and entrenchment of the notion that self-interest and public welfare are interchangeable has been underpinned by what we term 'charismatic violence': the mechanism by which the super-rich position themselves as transformational agents of change while functioning in practice as vanguards of an injurious status quo, fomenting rationales for extreme wealth concentration in a manner that is subtly different from what either Bourdieu and Tocqueville could foresee.

\section{Charismatic violence and proof of 'success'}

In the United States, the super-rich's proportion of wealth has increased massively in the last 30 years (Galbraith 2008; Hacker and Pierson 2010; Piketty 2014), and many can be seen to have used some of that increased wealth to reinforce the Tocquevillian sanctity of their position in the world order. Not only does their wealth in itself signify their exceptionality but that exceptionality is amplified by giving away large proportions of their wealth - ostensibly to individuals or groups who the donors do not know nor expect anything back in return. This form of mega-giving has generated a symbolic value so exceptional that is helped to cement a new form of secular theodicy driven by forms of quasi-religious authority and legitimation. ${ }^{8}$ 
Generating charisma through exceptional giving was, of course, not an unfamiliar practice to earlier elites performing, for example, potlach ceremonies - where their sacrificial offerings demonstrated their own exceptionality and godliness to their communities and to God itself. Nor is it an alien practice to the majority of organised religions where charity and assistance for the needy is enshrined in their liturgies and scriptures. Religion is also frequently bound into actual and symbolic representations of extraordinary giving - Jesus' giving of his life for 'us'; the monk or Sardou's giving of their material effects and comfort for austere devotion to God; Mother Teresa's gift of her life to help the poor; and, ultimately, God's gift of life itself.

Today's extraordinarily gifted - the super-rich who are celebrated in scriptures like Forbes and The Times Rich List and countless other media streams and outlets - are, of course, not generally understood or purported to be god's representatives on Earth. Yet, due to their apparent exceptional gifts and their exceptional giving, they are granted an almost sacred status. In a classic Durkheimian formulation, what is Godly is that which is given to humanity from the outside - and giving is itself Godly. Personal gift-giving echoes God's own sacrifice and is thus upheld as a sanctified activity that has worth far beyond any profane economic value. In this way, mega-giving by today's philanthrocapitalists produces a form of charismatic authority - and moreover, contra Bourdieu - this giving no longer needs to be separated from private economic advantage in order to be glorified as exceptional.

Philanthrocapitalist mega-gifts provoke awe not simply from those in receipt of the gift but also from most of those watching. The power of today's mega-giving is thus much broader than enrolling the direct receivers of gifts into a moral relationship, as Mauss posited, particularly through his discussions of the difficulty of rejecting a gift (1990: 41). Megagiving produces symbolic power - and symbolic costs - that affects recipients and nonrecipients alike. One major aspect of its symbolic costs is the way that voluntary gift-giving 
dissipates obligatory and collective demands for wealth redistribution, even while, paradoxically, elite donors speak of their 'duty' to give through extravagant gestures like the 'Giving Pledge'.

Sanctifying extreme individual wealth and privilege inevitably anoints unequal social and economic relations and, thus, inequality. Echoing Tocqueville's concerns about the poverty and brutalization resulting from the 'immobility' of the $19^{\text {th }}$ century labouring classes, social anthropologist Johan Galtung argues that 'when human beings are being influenced so that their actual somatic and mental realizations are below their potential realizations' (1969:168) this constitutes what he calls 'structural violence'. For Galtung, activities that sustain or increase inequality, whether intended or not, fuel suffering by limiting the equitable distribution of resources and 'lowering the level of needs satisfaction below what is potentially possible' (1990: 292). It may also be suggested that, while buttressing the renewed power of economic liberalism, the sanctification of the super-rich also works to maintain its supporting state systems. As has been observed by many, such states are fundamentally violent - constructing the life and death of their subjects (Mbembe, 2003; Farmer, 2004) and locking weaker states into dependence (Galtung, 1971). The sanctification of privilege and its ensuing inequality underpin both structural and actual violence.

One process through which structural violence is sustained is through what Galtung terms 'cultural violence' - different forms of obfuscation that make 'reality opaque, so that we do not see the violent act or fact, or at least not as violent' (1990: 292). In Galtung's view, the roots of cultural violence can be found most saliently in organised religion's use of cultural symbols and meanings that 'make direct and structural violence look, even feel right - or at least not wrong' (1990: 291) i.e. the process of theodicy. Adding to this, an aspect or subset of the power of cultural violence not identified by Galtung is the quasi-religious 
authority generated through charisma. Charisma - here buttressed by mega-giving - grants the super-rich a place on the social pulpit through which their activities and sermons empower the inegalitarian status quo and facilitate continued structural violence.

Thus, philanthrocapitalism - a notion that asserts that capitalist expansion, if left apparently unfettered by governmental restrictions, will yield universal benefits - is a fruitful narrative trope legitimating the imposition of domestic austerity measures and rising wealth transfers to corporations and affluent individuals, both domestically and internationally. However, the philanthrocapitalist's claim to their own inherent beneficence must, at least in theory, be embraced by a laity that needs reassurances that philanthrocapitalism has a purpose: that its gods or God wield legitimate authority. While part of this authority is generated through the charisma of almost other-worldly acts of mega-giving, it is also bolstered by philanthrocapitalist worldly reliance on the forceful rationality of apparently scientific 'proof'.

This proof is largely inculcated through careful efforts to delineate and disseminate a specific form of evidence of effectiveness, an effort that resonates with Weber's suggestion that individuals imbued with charismatic authority must furnish repeated proof of their grace in order to command allegiance:

If proof of his charismatic qualification fails him for long... above all, if his leadership fails to benefit his followers, it is likely that his charismatic authority will disappear. This is the genuine charismatic meaning of the 'gift of grace'... charismatic authority is thus specifically outside the realm of everyday routine and the profane sphere (Weber 2012: 360-361).

Weber's emphasis on the importance of charismatic proof helps to underscore the symbolic importance of the panoply of metrics and indices that are utilised by philanthrocapitalists to legitimate their practices (Adams 2015; Herrick 2017; Kelly \& Beisel 2011; Reubi 2013; 
Storeng and Béhague 2014; Fejerskov 2015; Street 2015). Yet, the apparently scientific and objective 'truth' of such metrics is bolstered by the sacred and symbolic power of the megagivers - hybridizing rational and sacred authority. It also raises new insights into the instrumental value of the host of new platforms that enable today's mega-donors to publicize their good deeds to global audiences, and how these platforms differ from the major benefactors of the past.

One difference is the tendency for today's super-rich to insist that their philanthropy contributes to narrowing wealth and health inequalities. In contrast to this, early benefactors such as Carnegie were famously sanguine about growing inequality levels; in Carnegie's words, 'much better this great irregularity than universal squalor' (Carnegie 1996: 1). Some of today's super-rich such as Peter Thiel, a libertarian and, somewhat paradoxically, an explicit monopolist, adopt a similar anti-egalitarian moral stance on growing inequality. However, mega-donors with the biggest media presence, including Gates and Zuckerberg, have long made equality a pillar of their public mission statements. 'We believe all lives have equal value,' is a phrase used by both Zuckerberg and the Gates Foundation repeatedly, with identical wording.

This creates an empirical quagmire: how to furnish proof of the effectiveness of private philanthropy at a time of global instability and rising inequality. We suggest that organizations such as the Gates Foundation accomplish this in two chief ways, both of which hinge on the ability to selectively exploit advantageous metrics when it comes to data gathering and data dissemination. Firstly, these donors rely on the usefulness of what we term 'low-hanging metrics'; and secondly, they often deliberately blur the line between the public and the private sectors, obscuring public understanding about which of those sectors are financially contributing to and profiting from new giving schemes that direct tax dollars and philanthropy bequests to private companies. In our final section below, we discuss these two 
points and consider their implications for understanding the persistence and worsening of social and economic inequality.

\section{Low-hanging metrics}

The new super-rich's ability to uphold themselves as global saviours with the clout and ability to 'end poverty' hinges on a new, muscular reliance on metrics that appears to confirm that large-scale philanthropy 'works' in saving lives and narrowing wealth and health inequalities - but which upon close inspection reveals the opposite: that increasingly topheavy philanthropy and new 'Giving Pledges' over the past 20 years have, at best, left global and national health and wealth inequality unaltered and, at worst, have exacerbated those inequalities (see Collins et al 2016; Hickel 2017; Reich 2006; Reid 2015).

This seeming inconsistency - the ability of a new class of donors to insist on the efficacy of their philanthropy despite the evidence on growing wealth and health inequalities that contradicts their claims - can be explained through closer attention to the way that powerful donors like the Gates Foundation strategically draw on evidence of varying quality to defend their insistence that 'the world is getting better.'

The majority of the Gates Foundation's giving over the past 15 years has gone to global rather than domestic causes, a focus that is in line with an increasingly dominant ethical paradigm within global development known as 'effective altruism' (EA). Taking its inspiration from $19^{\text {th }}$-century colonial utilitarian thinkers such as J.S. Mill and more contemporary thinkers like Peter Singer, contemporary EA advocates maintain that all philanthropic dollars should be targeted at areas where a fixed amount of money can create the most 'good'. Because gifts donated in dollars or euros purportedly 'save' more lives when 
spent in non-western regions, the EA movement asserts that citizens of western states have a moral duty to donate abroad rather than domestically.

Despite striking many as a laudable claim, effective altruism has faced robust criticism, including a recent paper from political theorist Georgina White who points out that ancient philosophers such as Aristotle conceived of the duty to give wisely in very different and important ways than that proposed by EA enthusiasts today. Aristotle stressed the need to give to those in one's personal community so that the impact of the gift could be observed directly (White 2017: 4). Aristotle was concerned that a gift should not make a recipient worse off - and close proximity was necessary for holding givers accountable to the recipients of their gifts.

Aristotle's point is instructive for thinking about new philanthrocapitalism movements and their lack of accountability to different global publics, especially to publics in poor regions with fewer resources to challenge the imposition of new policy measures (Hickel 2017; McGoey 2015), even when new initiatives do not reduce poverty and even exacerbate it, as in the case of microfinance initiatives (Gabor and Brooks 2016). ${ }^{9}$ But there's also another, different epistemological implication to local/global giving practices, which is the way that directing one's philanthropy at distant recipients confers a perceptual advantage that local giving efforts may not enjoy. If local giving can make it possible for both givers and recipients to judge and observe the effects of giving close at hand, the opposite is also true.

Distant donations make the direct effects of overseas aid and philanthropy usefully opaque and difficult to measure for donors and their spectators alike. The difficulty of tracking and measuring the effects of overseas aid is hardly a novel point: this reality has underpinned a massive recent increase in government, academic, and philanthropic funding aimed at doing a better job of measuring aid effectiveness. But what's less discussed is that 
the drive for better data collection has facilitated the appearance of metrics that appear to show significant gains in, for example, health or nutrition, but which on closer inspection are more attributable to introduction of the new metric itself.

New forms of measurement and data collection often yield 'low-hanging metrics': evidence that is easy to interpret in ways favourable to an underlying political or organizational objective. This appears to be particularly true of global health metrics, where almost any purported gain in global health is interpreted as evidence that private philanthropy is 'working.' To be clear, we are not suggesting that donors such as the Gates Foundation do not crave precision when it comes to measuring their impact - they do. Rather, our point is that even or, especially in cases where precise measurements are difficult or impossible to achieve, this lack of certainty furnishes useful epistemological advantages for donors advantages that help to reinforce perceptions of the validity of their 'theodicy of privilege'. This is the case in a number of situations where the seeming health gain is clearly an artefact of a new form of measurement rather than evidence of an actual health improvement.

The case of malaria reduction demonstrates this problem. Since the Gates Foundation began contributing approximately 1 to 2 billion dollars annually towards global health, the Foundation, and Gates personally, have made regular pronouncements about the 'miraculous' success of their efforts to reduce deaths from malaria. In 2016, for example, Gates hailed the results of a report from the Institute for Health Metric and Evaluation (IHME) which seemed to demonstrate that malaria death rates in sub-Saharan Africa had dropped 57 per cent since 2000. Gates described this purported drop as a 'miracle' and one of 'the greatest success stories in the history of global health'.

While it is true that there has been considerable improvement in malaria control over the last 20 years, Gates's claim exaggerates the scale of recent gains. For example, over recent years, a new malaria parasite resistant to artemisinin combination therapy (ACT) has 
appeared, leading to concern over spreading epidemics in southeast Asia, and to fears that mass drug administration programmes have compounded drug resistance. It is also the case that even when it comes to regions that have reported a large drop in malaria transmission rates, a close investigation of individual country reports can indicate that changes in diagnostic protocols - rather than clear evidence of lowered transmission rates - produced the appearance of a more dramatic decline in new infection rates than had actually occurred. For example, over 10 years ago, Senegal issued health guidance that heightened and tightened the requirements for officially recording malaria incidence rates. As anthropologist Marlee Tichenor (2015) describes, this change in protocol meant that following 2006, only laboratory-confirmed cases of malaria incidence were officially recorded. As a result, the rate of transmission seemed to improve more than it actually had. A 2012 Global Fund report on malaria-reduction in Senegal makes this problem clear, stating:

Reported cases of malaria in Senegal fell from more than 1.5 million in 2006 to 174,000 in 2009 . The main reason was a change in the case definition, with only laboratory-confirmed cases reported after 2008. There was some evidence of a real decrease in malaria incidence, although it was difficult to confirm (emphasis added; see also Tichenor 2017). ${ }^{10}$

In other words, a seemingly large drop - 1.5 million to less than 200,000 in three years - was an artefact of how incidence rates were recorded. The Global Fund couldn't determine whether there was any significant decrease in actual transmission during this period.

When organizations such as IHME report their findings, they are often careful to make it clear when their evidence base is weak. Yet Gates's much-publicized media pronouncements of a 'miraculous' decline in malaria rarely acknowledge the uncertainty over just how reliable the data are. The charisma of mega-donors like Gates also adds a level of 
credibility to the data, and the new philanthropists come to benefit from the impression that their philanthropic organizations are playing a 'miraculous' role in saving lives.

The Gates Foundation also tends to claim primacy for health gains that multiple actors working in global health helped to bring about, deliberately blurring the question of whether private philanthropy or government spending is most responsible for a particular health outcome. For example, in sheer dollar terms, Gates Foundation giving towards global health is negligible in comparison to what wealthy nations spend on overseas aid programmes. Although the Foundation's contribution of approximately $\$ 2$ billion to health and agriculture each year may seem like a lot of money, but it pales next to total overseas aid from OECD governments, which amounts to about $\$ 130$ billion annually. Gates Foundation's spending even pales in comparison to what most developing countries spend on social welfare and infrastructure building. Country to public perceptions in western nations, most of the revenue that developing countries spend on health comes from their own domestic revenues and not from development aid or private donors like the Gates Foundation. As a recent IHME report has emphasized: 'In most developing regions, government health spending that is financed by countries' own revenue is much larger than [development assistance for health] DAH' ${ }^{11}$

Although Gates Foundation staff do occasionally acknowledge that its expenditures are tiny compared to what poor and rich nations devote to global health, publicity material from the Foundation tends to convey a different message, often claiming erroneously to have played a major role in achieving global gains such as improved levels of absolute poverty even when those gains are attributable to factors entirely outside the remit or influence of the Foundation. Recent improvements in global poverty reduction, for example, are more attributable to China's state-led economic growth over the past 30 years than to any philanthropic bequests from the Gates Foundation or other private donors (Hickel 2017). 
It's also debatable whether data on poverty are calculated in accurate ways, and thus whether they are a useful measure of global welfare from which to claim any improvements. As Jason Hickel points out, efforts to measure global poverty reduction have shifted significantly since 1990, when the World Bank adopted the world's first international poverty line (IPL), which was then set at just over one dollar a day. As the World Bank acknowledged in its 2000 annual report, based on this figure, global poverty was on the rise. During that same year, the World Bank changed the IPL from 1.02 to 1.08 dollars per day. This seemed like an increase in what the World bank saw as a minimum limit but, in reality, the World Bank's new IPL was not increased in line with the declining purchasing power of the time. Indeed, in real terms, the figure of $\$ 1.08$ was lower than the $\$ 1.02$ figure. The effect, Hickel argues, was that 'The poverty headcount fell literally overnight... even though nothing had actually changed in the real world' (2017: 41). The figure later rose to $\$ 1.25$, and as of 2015 , was raised again to $\$ 1.90$. But this number is still seen as too low. Lant Pritchett, an economist based at Harvard, has called for the introduction of a new type of 'upper bound' poverty line that more fairly reflects the resources needed for a minimal level of well-being, and he places the figure at least $\$ 10$ per day.

Global poverty reduction figures also say little about rising absolute inequality between nations. On this score, the $20^{\text {th }}$ and $21^{\text {st }}$ centuries have been periods of gross divergence between nations. Economist Joseph Joyce points out than in 1870, average per capita income in world's richest nations in Europe and North America is estimated to have been $\$ 2,419$, while the average in African nations was $\$ 500$, a ratio of 5:1. By 1950, the gap had risen to 13:1. By 2003, the ratio was 18:1 (Joyce 2008).

\section{The erosion of obligation}


Extraordinary and often misleading claims from philanthrocapitalists also arise when it comes to their stance on corporate and wealth taxes - something that contrasts with concerns that Tocqueville raised about industrial manufacturing elites in the early nineteenth century.

As we have suggested, Tocqueville directed his appeals at industrial 'masters', exhorting them to consider the livelihoods of the working classes who were directly 'impoverished and brutalized' through industrial practices that restricted their capacity for personal growth and upward mobility. This form of violence, in Tocqueville's mind, required recompense for the injuries and injustices directly inflicted through wealth extraction. Yet, today, the idea that philanthropy should serve as such a form of expiation is largely rejected by the new philanthrocapitalists, who contest the idea that they should be obligated to any 'duty' to part with their wealth through measures such as taxation.

Zuckerberg's Facebook, for example, is embroiled in long-standing efforts to minimize tax obligations. In the autumn of 2016, Facebook informed the IRS in a court ruling that it would refuse to assume a federal tax liability of approximately $\$ 3$ billion (Kravets 2016). Notably, the figure was the exact amount that Zuckerberg had promised a month earlier to devote to medical research in order to, grandiosely, end or manage all human disease by the close of this century.

Other leading philanthropists have also upheld their philanthropy as a reason for rejecting tax obligations, including Bill Gates. Although Gates has sporadically called for increased capital gain taxes, he has consistently objected to policy efforts to make similar taxes a reality. Some of his clearest statements on this topic were made in the wake of the publication of Thomas Piketty's (2014) Capital in the $21^{\text {st }}$-Century, when Gates wrote a commentary rejecting Piketty's call for a global wealth tax. Gates offered a hypothetical picture of three people: 'One investing in companies, one in philanthropy, and one in a lavish 
lifestyle', adding that 'There's nothing wrong with the last guy, but I think he should pay more taxes than the others' (Gates 2014).

Remarkably, Gates appears to view the first two hypothetical figures as commensurate - those investing in 'companies' and those in 'philanthropy' - implying that these very distinctive practices are equally beneficial, and thus either approach should obviously offset tax burdens. Yet the claim that investing in 'companies' is intrinsically socially valuable fails to understand or to acknowledge Piketty's primary concern: that financial returns to private investors and private companies are exceeding national economic growth rates at alarming rates (Piketty uses the ratio of $\mathrm{R}>\mathrm{G}$ to symbolize this problem). Gates ignores Piketty's main premise, which is that rapid and disproportionate increases in private wealth are the root cause of growing inequality. Gates also objects to Piketty's concerns over the growth in 'rentier' wealth gains. In Gates' words: 'I fully agree that we don't want to live in an aristocratic society in which already-wealthy families get richer simply by sitting on their laurels and collecting what Piketty calls 'rentier income'... But I don't think America is anything close to that' (Gates 2014).

Gates associates 'rentier' wealth with wealth that is inherited from family estates. But this is a very narrow definition of 'rent' (Birch 2017; Hudson 2011; McGoey 2017; Sayer 2014). For instance, rentier returns can be obtained through intellectual property protections; through well-positioned real estate; through debt financing: in short, through a range of economic activities that leading mainstream economists such as Robert Solow (2015) have suggested require better regulation to ensure that returns to private investors are not grossly disproportionate to the services or products offered.

Through his narrow conception of economic rent and his firm belief that investment in private companies is inevitably beneficial for wider society, Gates is able to convey an influential notion of philanthropic munificence that is highly distinctive from the type of 
obligatory contract with the poor that Tocqueville called for. Indeed, the type of philanthropy extolled by figures such as Gates, Buffett and Zuckerberg is a form of giving without admitting ever having first taken and, it thus affords them, through the charisma that megagiving generates, immunity from criticism that even Balzac's nobles could not claim. It is a sense of assumed rather than imposed duty that denies responsibility for the condition of the poor to begin with; a duty rooted in fortunes that hail from such a diverse array of business practices that to suggest any singular 'class' connection seems almost conspiratorial - despite the fact that a new strata of business elites are clearly exerting global influence on tax policies and austerity measures that reinforce a self-serving approach to 'solving' global challenges.

The rejection of a legally enforceable obligation to relinquish one's wealth is clearly advantageous for individual donors and the super-rich more broadly, as it enables them to withstand mandatory redistributive measures such as higher corporate and wealth taxes, even while figures such as Gates and Buffett publicly profess that inequality troubles them.

Thus, returning to Tocqueville: the actions of contemporary philanthrocapitalists can be seen as a renewed embrace of an odd kind of elite duty - but the question of what obliges them to give is not as clear today as it was when aristocrats were so closely and clearly reliant on their 'subjects' and obligated by law or custom towards them. Instead exceptionally 'gifted' individuals like Gates or Zuckerberg appear to choose to give away almost impossible amounts of wealth - imbuing them with ever greater exceptionality. This voluntary nature of their giving plays an important role in legitimating their elevated social and economic position, positioning them to withstand calls for redistributive policy measures even as they appear to embrace the onus to surrender their privilege.

What unites today's global wealth elite is not their (post)industrial practices, which are so varied and complex that patterns of orchestrated exploitation are often hard to detect, criticize or prevent, but their emerging faith in a neo-feudal form of 'noblesse oblige' which, 
rather than being seen as a frightening return to a class-conscious aristocracy acting in unison to perpetuate their advantage, is viewed as an almost other-worldly action. Zuckerberg and Gates don't have to save the world, but they plan to anyway; an act of wilful largesse that makes their giving seem super-human and, at the same time, humanly replicable through apparent individual acts of sacrifice.

\section{Conclusion}

In this paper, we've suggested that benefactors such as Gates, Buffett and Zuckerberg function as specialized, sanctified figureheads of the market system. We are not claiming that they represent a permanent, immoveable stratum of business aristocrats in the specific manner that Tocqueville was concerned. Rather, generated out of their desire to morally justify their extreme wealth - through giving - they are effectively beginning to act in concert, and thus become more like a self-anointed collective of leaders, contributing to and solidifying the contemporary theodicy of privilege.

Moreover, in today's iteration of the 'new' philanthrocapitalism, we can see almost a complete reversal of Balzac's conception of 'noblesse oblige'. In Balzac's time, noblesse oblige conveyed the idea that those who were conferred privileges at birth have a moral onus to serve others. Today, this responsibility is willfully assumed by individuals such as Gates and Zuckerberg, but it is clearly and strategically upheld as a voluntary responsibility - partly or largely because these fortunes are deemed to have been generated through individual skill and hard work.

Yet, if the super-rich were compelled to hand over larger proportions of their wealth to the rest of a social community through taxation, their contribution to addressing disadvantage would remain within the domain of the profane - they would be just like their 
congregants. Instead, through upholding philanthropy as a legitimate reason for withstanding obligatory tax liabilities, they are provided the space to appear exceptional by apparently choosing to give vast amounts away for the purported betterment of the world. Through their elective giving, mega-donors come to constitute themselves as new nobility - while not necessarily conceding that parting with their wealth is something they 'must' do - in the same way that most individuals must, for example, pay tax. Thus the new business aristocracy represented by philanthrocapitalism suggests the emergence of a novel phenomenon that surpasses the entitlements and duties that nineteenth-century thinkers like as Tocqueville and Balzac attributed to a waning feudal aristocracy.

Whether the new industrial masters are more 'restrained' or 'dangerous' than earlier feudal lords requires more investigation. The question itself has been dormant for too long, obfuscated by a theodicy of privilege which makes the outlandish seem reasonable: that it is laudable and even dutiful for immiserated workers to salute the donor class for directing its philanthropy at itself. 


\section{References}

Allen, K. (2014, Jan 31) Official data shows longest fall in living standards for 50 years. The Guardian.

Allen, K., Mendick, H., Harvey, L., and Ahmad, A. (2015) Welfare Queens, Thrifty Housewives, and Do-it-All Mums: Celebrity motherhood and the cultural politics of austerity Feminist Media Studies 15(6): 907-925.

Aschoff, N. (2015) The New Prophets of Capital. London and New York, Verso.

Barnett, A. (2000) Corporate Populism and Partyless Democracy. New Left Review, May-June.

Barman, E. (2017) The Social Bases of Philanthropy Annual Review of Sociology 43, 271290.

Birn, A. E. (2014) Philanthrocapitalism, past and present: The Rockefeller Foundation, the Gates Foundation, and the setting(s) of the international/ global health agenda. Hypothesis 12(1): e8, doi:10.5779/hypothesis.v12i1.229

Birch, K. (2017) Commentary: Towards a theory of rentiership. Dialogues in Human Geography 7(1):109-111.

Bishop M, and Green M. (2008). Philanthrocapitalism: How the rich can save the world: Bloomsbury Press.

Boland, T and Griffin, R. (2016) Making sacrifices: how ungenerous gifts constitute jobseekers as scapegoats. Distinktion 17(2): 174-191.

Bourdieu, P. (1971) Une interprétation de la théorie de la religion selon Max Weber European Journal of Sociology / Archives Européennes de Sociologie 12(1): 3-21.

Bourdieu, P. (1990) The Logic of Practice. Cambridge, Polity Press.

Bourdieu, P. (1991) Genesis and Structure of the Religious Field Comparative Social Research, Vol. 13: 1-44.

Bourdieu, P, Schultheis, F and Pfeuffer, A. (2011) 'With Weber Against Weber: In Conversation with Pierre Bourdieu.' In S. Susen and B. Turner (Eds) The Legacy of Pierre Bourdieu: Critical Essays: 111-124.

Braemer, C. (2015) Philanthropy: The New Risk Capital? Stanford Social Innovation Review. October 23, 2015.

Braverman, H. (1974) Labor and Monopoly Capital: The Degradation of Work in the Twentieth Century New York: Monthly Review Press 
Carnegie, A. (1996). The 'Gospel of Wealth' Essays and Other Writings. Harmondsworth: Penguin.

Collin, C; Flannery, H, and Hoxie, J. (2016). Gilded Giving: Top-Heavy Philanthropy in an Age of Extreme Inequality, Institute for Policy Studies, Washington DC.

Cullen, L. and Madoff, R. (2016) 'The Undermining of American Charity' New York Times Review of Books, July 14.

Dugger, C. (2016) Dr. Susan Desmond-Hellmann, Guide of the Gates Foundation. New York Times, May 23.

Gabor D., and Brooks S.H. (2017) The Digital Revolution in Financial Inclusion: International development in the fintech era. New Political Economy. 22(4):423-436

Gates, B. (2014) 'Why Inequality Matters' Gatesnotes, October 13, 2014.

Edwards, M. (2010) Small Change: Why Business Won't Change the World. New York and London: Demos.

Eikenberry, A and Mirabella, (2017) 'Extreme Philanthropy: Philanthrocapitalism, Effective Altruism, and the Discourse of Neoliberalism' PS: Political Science and Politics, https://doi.org/10.1017/S1049096517001378

Eisinger, J. (2015) 'How Mark Zuckerberg's Altruism Helps Himself' New York Times, Dec 3.

Erickson, M. (2015) Class War: The Privatizaiton of Childhood. London and New York, Verso.

Farmer, P. (2004) 'An Anthropology of Structural Violence', Current Anthopology 45(3): 305-325.

Fisher D. (1983). The Role of Philanthropic Foundations in the Reproduction and Production of Hegemony - Rockefeller Foundations and the Social-Sciences. Sociology 17:206-33

Fejerskov, A. (2015). 'From unconventional to ordinary? The Bill and Melinda Gates Foundation and the Homogenising Effects of International Development Cooperation' Journal of International Development 27(2): 1098-1112.

Fourcade, M. (2011) 'Cents and Sensibility: Economic Values and the Nature of "Nature"' American Journal of Sociology 116(6): 1721-77.

Galbraith, J. (2008) The Predator State: How Conservatives Abandoned the Free Market and Why Liberals Should Too. Simon and Schuster: New York.

Galtung, J. (1969) 'Violence, Peace and Peace Research', Journal of Peace Research 6(3) 167-191. 
Galtung, J. (1971) 'A Structural Theory of Imperialism', Journal of Peace Research 8(2): 81-117.

Galtung, J. (1990) 'Cultural Violence', Journal of Peace Research 27(3) 291-305.

Goss, K. (2016) 'Policy Plutocrats: how America's Wealthy Seek to Influence Governance. PS: Political Science and Politics 49(3): 442-448

Harman, S. (2016) 'The Bill and Melinda Gates Foundation and Legitimacy in Global Health Governance' Global Governance 22(3): 349-368.

Hacker, J. and Pierson, P. (2010) Winner-Take-All Politics: How Washington Made the Rich Richer - and Turned its Back on the Middle Class. Simon and Schuster: New York.

Herrick, C. (2017) The (non)charisma of noncommunicable diseases. Social Theory and Health 15(1): 99-116

Himmelfarb, G (1997) 'Introduction,' in Tocqueville, A. (1997) Memoir on Pauperism. Ivan Dee publishers.

Hudson, M. (2011) 'Simon Patten on Public Infrastructure and Economic Rent Capture' American Journal of Economics and Sociology 70:873-903.

Jenkins, G. (2011) 'Who's afraid of philanthrocapitalism?' Case Western Reserve Law Review 61(3 ): 753-821.

Joosse, P. (2014) 'Becoming a God: Max Weber and the Social Construction of Charisma' Journal of Classical Sociology 14(3): 266-283.

Fridell, G. and Konings, M. (2013) 'Age of Icons: Exploring Philanthrocapitalism in the Contemporary World.' Toronto: University of Toronto Press.

Kelly, A and Beisel, U (2011) 'Neglected malarias: the frontlines and back alleys of global health.' BioSocieties 6:71-8.

Kish, Z. and Justin, L. (2015) 'Bonded Life: Technologies of racial finance from slave insurance to philanthrocapital' Cultural Studies, 29:5-6,

630-651, DOI: 10.1080/09502386.2015.1017137

Kravets, D. (2016). 'Facebook tells IRS it won't pay billions over Irish tax manoeuvre' Arstechnica, October 12.

Kohl-Arenas, E. (2016) The Self-Help Myth. University of California Press.

Kuldova, T. (2017). When Elites and Outlaws do Philanthropy: on the limits of private vices for public benefit. Trends in Organized Crime https://doi.org/10.1007/s12117-017-9323-6

Littler, J. (2013). Meritocracy as plutocracy: the marketising of 'equality' within neoliberalism. New Formations: a journal of culture/theory/politics, 80-81, pp. 52-72. doi: 10.3898/NewF.80/81.03.2013 
Mellor, P, and Schilling, C. (2014). Sociology of the Sacred: Religion, embodiment and social change. Sage.

Mbembe, A. (2003) 'Necropolitics', Public Culture 15(1): 11-40.

Mauss, M. (1990). The Gift: the form and reason for exchange in archaic societies. New York and London: Norton.

McGoey, L. (2012) Philanthrocapitalism and its critics Poetics 40(2): 185-199.

McGoey, L. (2015) No Such Thing as a Free Gift: The Gates Foundation and the Price of Philanthropy. London: Verso.

McGoey, L. (2017). The Elusive Rentier Rich: Piketty and the problem of absent evidence Science, Technology, and Human Values Vol. 42(2) 257-279.

Mears, A. (2015). Working for Free in the VIP: Relational Work and the Production of Consent. American Sociological Review 80(6) 1099-1122

Parmar, I. (2012) Foundations of the American Century: The Ford, Carnegie, and Rockefeller Foundations and the Rise of American Power Columbia University Press.

Piketty, T. (2014) Capital in the $21^{\text {st }}$ Century Cambridge, Mass: Harvard University Press.

Ravitch, D. (2010) The Death and Life of the Great American School System Basic Books.

Reich, R. (2006) "Philanthropy and Its Uneasy Relation to Equality," in William Damon and Susan Verducci, eds., Taking Philanthropy Seriously: Beyond Noble Intentions to Responsible Giving. Indianapolis: Indiana University Press: 27-50.

Reich, R., Cordelli, C. and Bernholz, L. (2016) Philanthropy in Democratic Societies: History, Institutions, Values. University of Chicago Press.

Reid, S. (2015). The Political Origins of Inequality: Why a More Equal World Is Better for Us All. University of Chicago Press.

Reubi, D. (2013) Health economists, tobacco control and international development: On the economisation of Global Health beyond neoliberal structural adjustment policies. Biosocieties, 8 (2), 205-228.

Rogers, R. (2011). Why philanthro-policymaking matters, Society 48: 376-381.

Schrift, A. (ed) (1997) The Logic of the Gift. London / Oxford: Routledge

Sayer, A. (2014) Why We Can't Afford the Rich. Polity.

Schambra, W. (2012). Is Conservative Philanthropy Ignoring the Poor?, Chronicle of Philanthropy, Feb 19. 
Singer, S. and Isaac, M. (2015) Mark Zuckerberg's Philanthropy Uses L.L.C. for More Control. New York Times, December 2.

Solow, R. (2015) ‘The Future of Work: Why Wages Aren't Keeping Up' Pacific Standard, August 11 .

Soskis, B. (2014). 'Both More and No More: The Historical Split between Charity and Philanthropy’ Hudson Institute report, October 15.

Stolz, J. (ed) (2008) Salvation Goods and Religions Markets: Theory and Applications Bern, Peter Lang.

Storeng, K. \& Béhague, D. (2014). 'Playing the Numbers Game': Evidence-based Advocacy and the Technocratic Narrowing of the Safe Motherhood Initiative. Medical Anthropology Quarterly 28(2): 260- 27

Storey, B. (2013) ‘Tocqueville on Technology’ The New Atlantis. Fall: 48-71.

Street, A. (2015) Food as pharma: marketing nutraceuticals to India's rural poor, Critical Public Health, 25:3, 361-372, DOI: 10.1080/09581596.2014.966652

Tichenor, M. (2016) Data Performativity and Malaria in Senegal. Paper delivered at the Evidence and Organizations in Development conference, Edinburgh, October 2016.

Tichenor, M. (2017) Data Performativity, Performing Health Work: Malaria and Labor in Senegal, Medical Anthropology, 36:5, 436-448

Thiel, D, Speed, E. and Cristo, S. (2015) The Impact of Welfare Reform in Essex: A Report for the Essex Housing Officers' Group. Working paper, Social Science Research Network: https://ssrn.com/abstract $=2853382$

Thorup, M. (2013). Pro Bono? On philanthrocapitalism as ideological answer to inequality. Ephemera, 13(3), 555-576.

Tocqueville, A. (1966[1835/1840]) Democracy in America. New York, Perennial Classics.

Tocqueville, A. (1997) Memoir on Pauperism. Ivan Dee publishers.

Tompkins-Stange, M. (2016) Policy Patrons: Philanthropy, Education Reform, and the Politics of Influence. Cambridge, Mass: Harvard Education Press.

Turner, B. (2013) The Religious and the Political: A Comparative Sociology of Religion. Cambridge University Press.

Weber, M. (2001). The Protestant Ethic and the Spirit of Capitalism. New York and London: Routledge Classics.

Weber, M. (1993) The Sociology of Religion. Beacon Press. 
Weber, M. (2012) The Theory of Social and Economic Organization Glencoe, Illinois: The Free Press.

Vogel, A. (2006) Who's making global civil society: philanthropy and US empire in world society British Journal of Sociology 57(4) 635-655

Zunz, O. (2011) Philanthropy in America: A History. Princeton University Press.

\section{Bios:}

Linsey McGoey is Reader in Sociology at the University of Essex, UK. She is author of No Such Thing as a Free Gift (2015) and The Unknowers (2018). She is a founding editor of the Routledge Research in Ignorance Studies book series, and with colleagues at Essex, she is part of the Human Rights and Big Data Technology project, funded by the ESRC.

Darren Thiel is Senior Lecturer in Sociology at the University of Essex, UK. He has published a number of works about the UK construction industry, social policy and criminal justice policy, including his book Builders: Class, Gender and Ethnicity in the Construction Industry (2012). He recently carried out an interviewed-based project on UK welfare reform, and is increasingly interested in studying the powerful.

\section{Acknowledgements}

The authors wish to thank Peter Wehling for assisting with a German translation, and Fran Tonkiss and Bronwyn Parry for helpful feedback during the development of the article. Thanks also to anonymous reviews for their constructive comments.

\footnotetext{
Notes

${ }^{1}$ Balzac's appeals to the righteousness of aristocratic rule were not, of course, merely nostalgic or symbolic: he wrote during the 1820 s to 1840 s, a time when aristocratic rights
} 
were rekindled under the reign of Louis Phillipe before all formal aristocratic privileges were abolished during the Revolution of 1848.

${ }^{2}$ The number of current 'pledgers' is derived from the Giving Pledge website, https://givingpledge.org/. This website lists profiles of individual pledgers, and includes copies of their 'pledge letters' (many addressed to 'Bill' personally). Having the funds to become a pledger is important: mere centi-millionaires are not welcome; the website emphasizes that the pledge is 'specifically focused on billionaires or those who would be billionaires if not for their giving.' Information about how much money has actually been given is not publicly available.

${ }^{3}$ One of the few contemporary scholars to mention the term is Benjamin Soskis in a compelling article on the historical origins of modern foundations (Soskis 2014).

${ }_{5}^{4}$ Quoted excerpts are available at http://philanthrocapitalism.net/about/faq/

5 That the Gates Foundation has strongly influenced domestic education policy in the US, for example, is beyond dispute (see Erickson 2015; Ravitch 2010; Tompkins-Stange 2016). For further discussion of the growing power and social implications of wealth elites, see Mears 2016, and Hickel 2017.

${ }^{6}$ Bourdieu takes the concept of 'theodicy of privilege' directly from Weber's notion of 'Theodizee des Glück.' German sociologist Peter Wehling indicates (personal communication) that Weber intends 'glück' to encompass things like honour, power, wealth, health and pleasure.

${ }^{7}$ Government data in the UK indicates that living standards in Britain have experienced the longest decline in recent years since records began. In the US, most wage levels have been stagnant in real terms for over 30 years (Allen 2014).

${ }^{8}$ One recent example of the religious tones of homage paid to the new mega-philanthropists stems from Bill Gates' $60^{\text {th }}$ birthday in October 2015. To mark the occasion, a school in Chennai, India organized a voluntary tribute to him. Over 1000 students gathered in a school year in military formation. They were each given a life-sized colour cut-out featuring a picture of Gates's face, which they raised above their heads in a coordinated salute. Amidst the rows of beaming children, a few volunteers held aloft a giant, 40-foot-high billboard featuring Gates' face and a slogan: 'Grow Rich. Help Others.'

${ }^{9}$ White is right to suggest today's effective altruists underestimate the moral importance of accountability for one's philanthropic actions. But she underestimates the centrality of Aristotlean notions within ethical positions outside of EA movements. Indeed, the ethical imperative to act 'locally' underpins longstanding conservative criticisms of foundations like Ford and Gates throughout the $20^{\text {th }}$ and $21^{\text {st }}$ centuries (see Schambra 2012).

${ }^{10} \mathrm{https}$ ://www.theglobalfund.org/media/2717/oig gfoig11007auditsenegal executivesummary en.pdf?u=636 488964650000000 (last accessed Feb 2018).

${ }^{11}$ http://www.healthdata.org/sites/default/files/files/policy_report/2011/FGH2011/IHME_FG H2011_Chapter3.pdf 